\title{
PENGARUH PENDIDIKAN KESEHATAN DENGAN METODE SIMULASI PERTOLONGAN PERTAMA (MANAGEMENT AIRWAY) PADA PENYINTAS DENGAN MASALAH SUMBATAN JALAN NAFAS PADA MASYARAKAT AWAM DI KEC.SAWIT KAB. BOYOLALI
}

\author{
Akhmad Rifai*1, ${ }^{\text {Sugiyarto }}{ }^{2}$ \\ Poltekkes Kemenkes Surakarta Jurusan Keperawatan
}

\begin{abstract}
Background: Airway management is the most important thing in resuscitation and requires special skills in the management of emergencies, therefore the first thing that must be assessed is the smoothness of the airway, which includes airway examinations that can be caused by foreign bodies. The lack of oxygen is a cause of rapid death. Research Objectives The general objective of this research is to improve the ability of airway management skills ordinary people in Kateguhan, Sawit, Boyolali. Methods: This research is an experimental study with a Pre-Test-Post Test one Group control design approach. through testing research hypotheses. The population of this research is the cloud community of 50 respondents which are divided into two groups, 25 respondents in the intervention group and 25 respondents as a control group. Statistical test in the paired group uses the nonparametric Wilcoxon test and the non-paired uses Mann-Whitney. Results: Based on the results of the Wilcoxon analysis test it can be concluded that the 25 respondents who conducted training in simulation measures by way of air way management training specifically airway obstruction can be drawn the conclusion that the majority of ordinary people have good knowledge in terms of emergency handling abilities, especially in air way management measures $p$ value 0.001 which means that there are significant differences between before and after training. In the control group there were also significant differences with a $P$ value of 0.001. Based on the Mann-Whitney test analysis, there were significant differences between the intervention and control groups with a $p$ value of 0.001. Conclusion: Airway management education and training courses for lay people continue to be held to improve the ability of the action skills.
\end{abstract}

Keywords: Airway management skills, Ordinary people

\section{PENDAHULUAN}

Menurut Bingham (2008), airway management adalah prosedur medis yang dilakukan untuk mencegah obstruksi jalan napas untuk memastikan jalur nafas terbuka antara paru-paru pasien dan udara luar. Hal ini dilakukan dengan membuka jalan nafas atau mencegah obstruksi jalan napas yang disebabkan oleh lidah, saluran udara itusendiri, benda asing, atau bahan dari tubuh sendiri, seperti darah dan cairan lambung yang teraspirasi. Menurut ATLS (Advance Trauma Life Support) (2008), Airway manajemen merupakan hal yang terpenting dalam resusitasi dan membutuhkan keterampilan yang khusus dalam penatalaksanaan keadaan gawat darurat, oleh karena itu hal pertama yang harus dinilai adalah kelancaran jalan 
nafas, yang meliputi pemeriksaan jalan nafas yang dapat disebabkan oleh benda asing, fraktur tulang wajah, fraktur manibula atau maksila, fraktur laring atau trakea. Gangguan airway dapat timbul secara mendadak dan total, perlahan-lahan dan sebagian, dan progresif dan/atau berulang. Kejadian yang berupa kematiankematian dini karena masalah airway seringkali masih dapat dicegah, dan dapat disebabkan oleh kegagalan mengetahui adanya kebutuhan airway, ketidakmampuan untuk membuka airway, kegagalan mengetahui adanya airway yang dipasang secara keliru, perubahan letak airway yang sebelumnya telah dipasang, kegagalan mengetahui adanya kebutuhan ventilasi dan aspirasi isi lambung ATLS (Advance Trauma Life Support, 2008). Dalam airway manajemen terdapat tiga jenis airway definitif yaitu: pipa orotrakeal, pipa nasotrakeal, dan airway surgical (krikotiroidotomi atau trakeostomi) . Penentuan pemasangan airway definitif didasarkan pada penemuan-penemuan klinis antara lain adanya apnea, ketidakmampuan mempertahankan airway yang bebas dengan cara-cara yang lain, kebutuhan untuk melindungi airway bagian bawah dari aspirasi darah atau vomitus, ancaman segera atau bahaya potensial sumbatan airway, adanya cedera kepala yang membutuhkan bantuan nafas (GCS $<8)$, ketidakmampuan mempertahankan oksigenasi yang adekuat dengan dan pemberian oksigen tambahan lewat masker wajah ATLS (Advance Trauma Life Support, 2008). Manajemen jalan napas pra-rumah sakit merupakan komponen utama system emergency medical service (EMS) di seluruh dunia, yang harus dikendalikan dengan baik dalam tindakan resusitasi. Pengembangan teknik dan peralatan manajemen jalan napas pra-rumah sakit yang berbeda mencerminkan evolusi triase pra-rumah sakit dan penatalaksanaan emergency (Jacobs,Grabinsky 2014). Pengendalian jalan napas yang tidak baik telah diidentifikasi menjadi penyebab kecacatan bahkan kematian yang dapat dicegah pada pasien trauma dan henti jantung. Cara penanganan jalan napas yang efektif harus tercapai sebelum pasien tiba di rumah sakit, hal ini tidak mudah serta beberapa hal masih controversial (Lockey DJ, Crewdson K, Louis HM 2014). Keberhasilan pertolongan terhadap penderita gawat darurat sangat tergantung dari kecepatan dan ketepatan dalam memberikan pertolongan. Semakin cepat pasien ditemukan makasemakin cepat pula pasien tersebut mendapat pertolongan sehingga terhindar dari kecacatan ataukematian. Kondisi kekurangan oksigen merupakan penyebab kematian yang cepat. Kondisi inidapat diakibatkan karena masalah sistem pernafasan ataupun bersifat sekunder akibat darigangguan sistem tubuh yang lain. Pasien dengan kekurangan oksigen dapat jatuh dengan cepat ke dalam kondisi gawat darurat sehingga memerlukan pertolongan segera. Apabila terjadi kekurangan oksigen 6-8 menit akan menyebabkan kerusakan otak permanen lebih dari 1" menit akan menyebabkan kematian. oleh karena itu pengkajian pernafasan pada penderita gawat darurat penting dilakukan secara efektif dan efisien

\section{METODE PENELITIAN}

Jenis penelitian ini adalah penelitian komparatif kategorik dua kali pengukuran dengan pendekatan cross-sectional. Pengumpulan data pada penelitian ini dilakukan dengan memberikan kuesioner, 
sebelum pelatihan dan melakukan pelatihan bagaimana menolong penyintas dengan gangguan obstruksi jalan nafas dan di observasi setelah pelatihan yang bertujuan untuk menganalisa variabel bebas dan variabel terikat. Pelaksanaan teknik sampling dalam penelitian ini menggunakan random sampling dengan cara memilih secara acak dari 250 populasi sebesar 50 responden. Dari 50 responden di bagi menjadi dua kelompok secara acak yaitu 25 responden sebagai kelompok intervensi atau dilakukan pelatihan management airway dengan simulasi dan demonstrasi dan 25 responden sebagai kelompok control yaitu dilakukan pelatiahan dengan melihat video bagaimana cara menolong penyintas dengan gangguan jalan nafas. Analisis data baik kelompok intervensi maupun kelompok control dengan menggunakan uji beda Willcoxon test sedangangkan yang tidak berpasangan atau independent menggunakan uji Mann-Whitney

\section{HASIL PENELITIAN}

Tabel 1. Distribusi Frekuensi Responden Berdasarkan Kelompok Umur pada Kelompok Intervensi maupun Kelompok kontrol

\begin{tabular}{lrrrc}
\hline \multirow{2}{*}{ Umur } & \multicolumn{2}{c}{ Frekuensi } & \multicolumn{2}{c}{ Persentase (\%) } \\
\cline { 2 - 5 } & intervensi & kontrol & intervensi & kontrol \\
\hline $11-15 \mathrm{Th}$ & - & 11 & - & 44 \\
16-20 Th & 22 & 11 & 88 & 44 \\
21 ke atas & 3 & 3 & 12 & 12 \\
\hline Jumlah & $\mathbf{2 5}$ & $\mathbf{2 5}$ & $\mathbf{1 0 0}$ & $\mathbf{1 0 0}$ \\
\hline \multicolumn{3}{c}{ Berdasarkan tabel } & 1 pada kelomok \\
intervensi dari & 25 responden, responden \\
dengan umur 16 - 20 tahun yaitu 22 orang \\
(88\%), umur 20 tahun keatas 3 orang \\
(12\%) Sehingga tabel di atas dapat \\
disimpulkan bahwa mayoritas responden \\
berumur antara 16 - 20 tahun. Pada \\
kelompok control responden yang \\
berumur antara 11-15 tahun sebanyak 11
\end{tabular}

orang (44\%),16-20 tahun 11 orang (44\%) dan umur 21 keatas hanya 3 orang (12\%)

Tabel 2. Distribusi Frekuensi Responden Berdasarkan Jenis Kelamin Responden pada Kelompok Intervensi dan Kelompok Kontrol

\begin{tabular}{|c|c|c|c|c|}
\hline \multirow{2}{*}{$\begin{array}{l}\text { Jenis } \\
\text { Kelamin }\end{array}$} & \multicolumn{2}{|c|}{ Frekuensi } & \multicolumn{2}{|c|}{ Persentase (\%) } \\
\hline & $\overline{\text { interve }}$ & ontrol & interven & ontrol \\
\hline Laki - laki & 8 & 10 & 32 & 40 \\
\hline Perempuann & 17 & 15 & 68 & 60 \\
\hline Jumlah & 25 & 25 & 100 & 100 \\
\hline
\end{tabular}

responden, responden dengan jenis kelamin laki-laki adalah 8 orang $(32 \%)$ sedangkan dengan jenis kelamin peempuan adalah 17 orang (68\%), sehingga dapat disimpulkan bahwa antara reponden laki-laki dan perempuan jumlahnya lebih banyak perempuan. Pada kelompok control 25 responden, responden dengan jenis kelamin laki-laki adalah 10 orang $(40 \%)$ sedangkan dengan jenis kelamin perempuan adalah 15 orang (60\%), sehingga dapat disimpulkan bahwa antara reponden laki-laki dan perempuan jumlahnya lebih banyak perempuan

Tabel 3. Distribusi Frekuensi Responden Berdasarkan Tingkat Pendidikan pada Kelompok Intervensi dan kelompok Kontrol

\begin{tabular}{lcccc}
\hline \multirow{2}{*}{ Pendidikan } & \multicolumn{2}{c}{ Frekuensi } & \multicolumn{2}{c}{$\begin{array}{c}\text { Persentase } \\
(\%)\end{array}$} \\
\cline { 2 - 5 } & \multicolumn{2}{c}{ intervensi kontrol } & intervensi kontrol \\
\hline SD & 1 & - & 4 & - \\
SMP & 2 & 8 & 8 & 32 \\
SMA & 20 & 15 & 80 & 60 \\
Sarjana & 2 & 2 & 8 & 8 \\
\hline Jumlah & $\mathbf{2 5}$ & $\mathbf{2 5}$ & $\mathbf{1 0 0}$ & $\mathbf{1 0 0}$ \\
\hline
\end{tabular}

Berdasarkan tabel 3 dari 25 responden, responden pada kelomok intervensi dengan tingkat pendidikan SD sebanyak 1 orang (4\%), SMP 2 orang (8\%), SMA 20 orang (80\%), dan Sarjana sebanyak 2 orang $(8 \%)$. Sehingga dapat 
disimpulkan bahwa mayoritas responden berpendidikan SMA atau sederajat. Pada kelompok kontrol responden dengan tingkat pendidikan, SMP 8 orang (32\%), SMA 15 orang (60\%), dan Sarjana sebanyak 2 orang (8\%).Sehingga dapat disimpulkan bahwa mayoritas responden berpendidikan SMA atau sederajat. Dari kedua kelompok baik kelompok intervensi maupun kelompok kontrol responden mayoritas berpendidikan SMA atau sederajat.

Tabel 4. Tingkat Kemampuan Responden Sebelum dan Sesudah Pelatihan Management airway pada Kelompok Intervensi

\begin{tabular}{llcccc}
\hline \multirow{2}{*}{ Variabel } & & \multicolumn{4}{c}{ Pelatihan } \\
\cline { 3 - 6 } & & \multicolumn{3}{c}{ Pre } & \multicolumn{3}{c}{ Post } \\
\cline { 3 - 6 } & & $\mathrm{n}$ & $\%$ & $\mathrm{n}$ & $\%$ \\
\hline Tingkat & Buruk & 6 & 24 & - & 0 \\
Kemampuan & Kurang & 17 & 68 & - & 0 \\
Management & Cukup & 2 & 8 & 4 & 4 \\
Airway & Baik & - & & 96 & 96 \\
\hline
\end{tabular}

Tabel 4 diatas menyajikan hasil dari 25 responden, dengan tingkat kemampuan pelatihan management airway sebelum pelatihan dengan kemampuan buruk 6 orang (24\%) kurang 17 responden $(68 \%)$ cukup 2 responden $(8 \%)$ dan hasil sesudah dilakukan pelatihan management airway dengan hasil cukup 4 responden (4\%) dan dengan hasil baik 96 responden (96\%).

Tabel 5. Tingkat Kemampuan Responden Sebelum dan Sesudah Pelatihan Management Airway pada Kelompok Kontrol

\begin{tabular}{llllll}
\hline \multirow{2}{*}{ Variabel } & \multicolumn{4}{c}{ Pelatihan } \\
& & \multicolumn{3}{c}{ Panagement airway } \\
\cline { 3 - 6 } & & $\mathrm{n}$ & $\%$ & $\mathrm{n}$ & $\%$ \\
\hline Tingkat & Buruk & 4 & 16 & - & - \\
kemampuan & Kurang & 15 & 60 & - & - \\
\hline
\end{tabular}

\begin{tabular}{llllll}
\hline management & Cukup & 6 & 24 & 13 & 52 \\
airway & Baik & - & - & 12 & 48 \\
\hline
\end{tabular}

Tabel 5 diatas menyajikan hasil dari 25 responden, dengan tingkat kemampuan pelatihan management airway pada kelompok kontrol sebelum pelatihan dengan kemampuan buruk 4 orang (16\%) kurang 15 responden $(60 \%)$ cukup 6 responden (24\%) dan hasil sesudah dilakukan pelatihan management airway dengan video dengan hasil cukup 13 responden (52\%) dan dengan hasil baik 12 responden $(48 \%)$.

Tabel 6. Hasil Analisis Uji Willcoxon Tingkat Kemampuan Responden Sebelum dan Sesudah dilakukan Pelatihan Management Airway pada Kelompok Intervensi

\begin{tabular}{|c|c|c|c|c|}
\hline Variabel & $\mathbf{n}$ & Median & Min-Max & $\overline{p \text {-value }}$ \\
\hline $\begin{array}{l}\text { Tingkat } \\
\text { kemampuan } \\
\text { responden } \\
\text { sebelum } \\
\text { Pelatihan } \\
\text { management } \\
\text { airway }\end{array}$ & 25 & 2 & $1-3$ & \\
\hline $\begin{array}{l}\text { Tingkat } \\
\text { kemampuan } \\
\text { responden } \\
\text { sesudah } \\
\text { pelatihan } \\
\text { management } \\
\text { airway }\end{array}$ & 25 & 4 & $3-4$ & 0,0001 \\
\hline
\end{tabular}

Berdasarkan tabel 6 dari 25 responden, tingkat kemampuan tindakan management airway sebelum pelatihan dengan hasil median 2 dan minimal 1 dan maksimal 3 sedangkan pada tingkat kemampuan management airway sesudah pelatihan dengan hasil median 4 dan minimal 3 dan maksimal 4. Adapun hasil dari $P$ value 0,001 yang artinya ada perbedaan yang signifikan antara sebelum dan sesudah dilakukan pelatihan management airway 
Tabel 7. Hasil Analisis Uji Willcoxon Tingkat Kemampuan Responden Sebelum dan Sesudah dilakukan Pelatihan Management Airway pada Kelompok Kontrol

\begin{tabular}{|c|c|c|}
\hline Variabel & $\underline{\mathbf{n}}$ & Median Min-Max p-value \\
\hline $\begin{array}{l}\text { Tingkat } \\
\text { kemampuan } \\
\text { responden } \\
\text { sebelum } \\
\text { pelatihan } \\
\text { management } \\
\text { airway }\end{array}$ & 25 & $1-3$ \\
\hline $\begin{array}{l}\text { Tingkat } \\
\text { kemampuan } \\
\text { responden } \\
\text { sesudah } \\
\text { pelatihan } \\
\text { management } \\
\text { airway } \\
\end{array}$ & 25 & $3-4$ \\
\hline $\begin{array}{l}\text { Berd } \\
\text { responden, } \\
\text { managemer } \\
\text { kontrol sel } \\
\text { median } 2 \mathrm{~d} \\
\text { sedangkan } \\
\text { managemer } \\
\text { dengan has } \\
\text { maksimal } \\
0,0001 \text { yan } \\
\text { signifikan } \\
\text { dilakukan } \\
\text { dengan Vid }\end{array}$ & $\begin{array}{l}\mathrm{m} \\
\mathrm{min} \\
\mathrm{ada}\end{array}$ & $\begin{array}{l}\text { tabel } 7 \text { dari } 25 \\
\text { kemampuan tindakan } \\
\text { ay pada kelompok } \\
\text { elatihan dengan hasil } \\
\text { nal } 1 \text { dan maksimal } 3 \\
\text { tingkat kemampuan } \\
y \text { sesudah pelatihan } \\
3 \text { dan minimal } 3 \text { dan } \\
\text { in hasil dari } P \text { value } \\
\text { ada perbedaan yang } \\
\text { sebelum dan sesudah } \\
\text { management airway }\end{array}$ \\
\hline
\end{tabular}

Tabel 8. Hasil Analisis Uji Mann-whitney Tingkat Kemampuan Responden Management Airway antara Kelompok Intervensi dan Kelompok Kontrol

\begin{tabular}{lcccc}
\hline Variabel & n & Median & Min-Max & p-value \\
\hline $\begin{array}{l}\text { Tingkat } \\
\text { kemampuan } \\
\text { responden }\end{array}$ & & & & \\
$\begin{array}{l}\text { sebelum } \\
\begin{array}{l}\text { Pelatihan } \\
\text { management }\end{array}\end{array}$ & 25 & 2 & $1-3$ & \\
airway & & & & \\
& & & & 0,0001
\end{tabular}

$\begin{aligned} & \text { Tingkat } \\ & \text { kemampuan } \\ & \text { responden } \\ & \text { sesudah }\end{aligned}$
$\begin{aligned} & \text { pelatihan } \\ & \text { management } \\ & \text { airway }\end{aligned}$

Berdasarkan tabel 8 dari 25 responden, tingkat kemampuan tindakan management airway pada kelompok kontrol sebelum pelatihan dengan hasil median 2 dan minimal 1 dan maksimal 3 sedangkan pada tingkat kemampuan management airway sesudah pelatihan dengan hasil median 3 dan minimal 3 dan maksimal 4. Adapun hasil dari $p$ value 0,0001 yang artinya ada perbedaan yang signifikan antara sebelum dan sesudah dilakukan pelatihan management airway dengan Video

\section{PEMBAHASAN}

Tempat dan lokasi penelitian ini adalah di Sobayan Kateguhan sawit Boyolali jawa tengan. Jumlah responden pada penelitian ini adalah 50 responden yang terbagi menjadi dua kelompok. Kelompok intervensi 25 responden dan 25 responden kelompok kontrol. Responden pada kelompok intervens maupun kelompok kontrol Sebelum pemberian materi pelatihan tindakan management airway pada responden, keduanya terlebih dahulu dilakukan pre test untuk mengukur tingkat kepengetahuan dan ketrampilan responden.

Pelaksanaan pelatihan responden di bagi menjadi 2 kelas, setiap kelas terdiri dari 25 responden, yaitu laki-laki 8 orang dan perempuan 17 orang pada kelompok intervensi dan laki-laki 10 dan 15 orang responden pada kelompok kontrol . Hasil dari penelitian ini didapatkan bahwa jumlah responden mayoritas perempuan dan umur rata-rata diantara 16 sampai 
dengan 20 tahun sedangkan pendidikan rata-rata SMA .

Hasil penelitian menunjukkan bahwa dari 25 responden pada kelompok intervensi, sebelum dilakukan management airway terdapat 6 orang (24\%) dengan tingkat kemampuan buruk, tingkat kemampuan kurang ada 17 orang (68\%) dan tingkat kemampuan baik ada 2 orang. Setelah dilakukan pendidikan dengan cara simulasi dan demontrasi tentang management airway terdapat 4 orang (4\%) dengan tingkat kemampuan cukup, dan tingkat kemampuan baik ada 96 orang (96\%). Hasil uji analisis menggunakan uji non parametric Wilcoxon, di dapatkan bahwa Tingkat kemampuan melakukan management airway meningkat dengan nilai $p$-value $=$ 0,001 yang berarti bahwa setelah dilakukan pelatihan tindakan management airway, ada perbedaan yang bermakna terhadap tingkat kemampuan melakukan management airway khususnya tindakan penanganan sumbatan jalan nafas pada masyarakat awam. Pada kelompok kontrol dari 25 responden, sebelum dilakukan management airway terdapat 4 orang (16\%) dengan tingkat kemampuan buruk, tingkat kemampuan kurang ada 15 orang (60\%) dan tingkat kemampuan cukup 6 orang. Setelah dilakukan pendidikan dengan cara melihat video simulasi tentang management airway terdapat 13 orang (52\%) dengan tingkat kemampuan cukup, dan tingkat kemampuan baik ada 12 orang ( $48 \%)$. Hasil uji analisis menggunakan uji non parametric Wilcoxon, di dapatkan bahwa Tingkat kemampuan melakukan management airway meningkat dengan nilai $\mathrm{p}$ value $=$ 0,001 yang berarti bahwa setelah dilakukan pelatihan tindakan management airway dengan melihat video simulasi , yang artinya ada perbedaan yang bermakna terhadap tingkat kemampuan melakukan management airway khususnya tindakan penanganan sumbatan jalan nafas pada masyarakat awam. Pada penelitian ini dapat di simpulkan bahwa setelah dilakukan pelatihan management airway baik pada kelomopk intervensi dan kelompok kontrol tingkat pengetahuan dan dan ketrampilan masyarakat awam meningkat. Berdasarkan hasil analisis uji Mann-Whitney ada perbedaan yang bermakna antara kelompok intervensi dan kelompok kontrol pada tingkat kemampuan responden dalam penanganan management airway khususnya sumbatan jalan nafas

Ketepatan tindakan management airway pada pasien atau korban dengan sumbatan jalan nafas akan mengurangi resiko gagal nafas. Hal ini juga didukung oleh dampak cedera yaitu lama rawat inap akibat cedera tidak berbeda berdasarkan jenis pekerjaan. aktor yang berperan terhadap lama rawat inap adalah jenis, penyebab, dan tempat kejadian cedera. Lama rawat inap 7 hari ke atas berperluang berisiko 21 kali pada jenis cedera gegar otak, 6,3 kali pada cedera patah tulang, 3 kali pada cedera mata, 2,1 kali pada cedera KLL, dan 1,7 kali pada cedera yang terjadi di bisnis/industri/ konstruksi/pertanian (Tana. L 2016).

Gagal nafas merupakan ketidakmampuan alat pernafasan untuk mempertahankan oksigenasi didalam darah dengan atau tanpa penumpukan CO2. Terdapat 6 sistem kegawatan salah satunya adalah gagal nafas yang menempati urutan pertama. Hal ini dapat dimengerti karena apabila terjadi gagal nafas waktu yang tersedia terbatas sehingga memerlukan ketepatan dan kecepatan dalam bertindak. Untuk itu 
harus dapat mengenal tanda-tanda dan gejala gagal nafas dan menanganinya dengan cepat walaupun tanpa menggunakan alat yang canggih (Nemaa PK. 2003). khususnya pada masyarakat awam yang sering menjumpai kejadian pada kasus gagal nafas khususnya sumbatan jalan nafas.

Pada pasien dengan kesadaran umum komposmentis, tanda dan gejala obstruksi saluran napas atas, antara lain distress pernapasan, perubahan suara, disfagia, odinofagia, tanda tersedak, stridor, pembengkakan muka, dan takikardia. Pada pasien dengan penurunan kesadaran, gejala utama dari obstruksi saluran napas atas adalah adanya ketidakmampuan untuk ventilasi dengan bag valve mask setelah percobaan membuka jalan napas dengan teknik jaw thrust. Setelah obstruksi saluran napas atas berlangsung beberapa menit, asfiksia dapat menyebabkan sianosis, bradikardia, hipotensi, kolaps kardiovaskular bersifat ireversibel. Kadang-kadang obstruksi saluran napas atas dapat berkembang secara perlahan. Obstruksi hidung atau stridor dipikirkan sebagai tanda spefisik dari obstruksi saluran napas atas. Stridor terdengar pada semua siklus respirasi, namun biasanya terdengar lebih intensif pada saat inspirasi dan lebih menonjol di atas leher. Adanya stridor mengindikasikan obstruksi saluran napas yang berat (aliran udara) itu tidak dapat membantu penentuan lokasi obstruksi (Jose C, Atul C. 2009)

Selama pelaksanaan penelitian ini terdapat beberapa kendala, diantaranya adalah pada saat pre test dan post test, responden lesehan dan membaur sehingga memungkinkan responden melakukan diskusi tentang jawaban pertanyaan dari kuesioner yang dikerjakan. pada saat test berlangsung tempat duduk responden diberi jarak selayaknya pada saat pelaksanaan ujian. Sehingga dengan adanya kendala tersebut, pada saat pelaksanaan test menggunakan ruangan sampai ke luar kelas untuk mengantisipasi atau meminimalisasi diskusi saat pelaksanaan pre tes maupun post test agar hasil kegiatan pelatihan maksimal.

\section{KESIMPULAN DAN SARAN}

Ada perbedaan yang bermakna antara sebelum dan sesudah dilakukan pelatihan tindakan management airway baik pada kelompok intervensi dan kelompok kontrol dan ada perbedaan yang bermakna antara kelompok intervensi dan kelompok kontrol

Setiap masyarakat awam harus memiliki kemampuan penanganan tindakan management airway khususnya pada sumbatan jalan kedaruratan sumbatan jalan nafas, karena masyarakat awam yang sering menemui kejadiankejadian pada penyintas dengan masalah sumbatan jalan nafas. Dengan demikian pelatihan dan simulas tentang managent airway sebaiknya di update secara rutin bagi masyarakat awam

\section{DAFTAR RUJUKAN}

Advanced Trauma Life Support (ATLS) For Doctors.2015.8th Edition.

American College of Surgeons.2010. Advanced Trauma Life Support (ATLS, 2010) Untuk Dokter Edisi 7. Jakarta : IKABI, Bab 5; Trauma Abdomen.

American Heart Association (AHA), 2015, Adult Basic Life Support: Guidelines for cardiopulmonary Resuscitation and Emergency Cardiovascular Care, diakses 16 
oktober 2016,http ://circ.aha. Journals.org/content/122/16 suppl 2/S298.

Bingham, Robert M.; Proctor, Lester T.2008. Airway Management. Pediatric Clinics of North America. 55 (4): 873-886. Diakses dari

Guildner CW. Resuscitation--opening the airway. A comparative study of techniques for opening an airway obstructed by the tongue. JACEP 1976;

5:588. https://www.ncbi.nlm.nih.gov/pub med/18675024 pada 11 Oktober 2016.

Jacobs PE, Grabinsky A. Advances in prehospital airway management. International. Journal of Critical Illness \& Injury Science [Internet]. 2014 [cited 2017 Aug 27]; 4(1):5764. Available from: Available from:https://www.ncbi.nlm.nih.go v/ pmc/ articles/ PMC3982372/

James Duke MD, MBA,2011. in Anesthesia Secrets (Fourth Edition).

Joffe AM, Hetzel S, Liew EC. A twohanded jaw-thrust technique is superior to the one-handed "ECclamp" technique for mask ventilation in the apneic unconscious person. Anesthesiology 2010; 113:873.

Lockey DJ, Crewdson K, Louis HM. Prehospital anesthesia; The same but different. British Journal of Anesthesia [Internet]. 2014 [cited 2017 Aug 27];113(2):211-9. Available from: http://www.medscape.com/viewart icle/829160_1
Mansjoer, Arif., et al (eds), Kapita Selekta Kedokteran ed.III, jilid 1, FKUI, Media Aesculapius, Jakarta. 1999.pp; 96-99

Mark A. Graber dan Laura Beaty, Otolaringologi: Dewi, Susilawati, editor, Buku Saku Kedokteran Keluarga University of IOWA, ed.3, EGC, Jakarta, 2006, 745-747

Notoatmodjo, Soekidjo. Metodologi Penelitian Kesehatan. Cetakan Pertama. Rineka Cipta, Jakarta. 2010

Nursalam.2008. Konsep dan Penerapan Metodologi Penelitian Ilmu Keperawatan. Edisi 2. Jakarta : Salemba Medika. 